\begin{tabular}{ll}
\hline \hline MINING AND METALLURGY INSTITUTE BOR & ISSN: 2334-8836 (Štampano izdanje) \\
UDK: 622 & ISSN: 2406-1395 (Online) \\
\hline \hline
\end{tabular}

\title{
SEGREGATION OF IMPURITIES IN PLATINUM AND PLATINUM-BASED ALLOYS ${ }^{* * *}$
}

\begin{abstract}
This work presents the research results of formation the equilibrium and non-equilibrium segregations of impurities both in pure platinum and platinum alloys. It is shown that segregations strengthen in the case when impurities, absorbed on the surface of crystals, have the same sign or similar values of range deviations regarding to the pure platinum. Equilibrium of segregations occurs as the diffusion result of impurities to the grain boundaries with creation of concentration gradient.

Non-equilibrium segregation of impurities occupies the area size of ten micrometers and is generated in the process of metal crystallization or in solid solution as the result of interaction the impurities with vacancies with formation a pair of vacancy-interstitial atom.

Segregation of impurities in the platinum alloys is conditioned by the nature of impurities, their concentration, distribution in the volume of metal, interaction with the basic and alloying components as well as the temperature - time factor.

The groups of impurities were observed in the form of foreign inclusions along with the equilibrium and non-equilibrium segregation of impurities in the platinum alloys.

Keywords: impurities, equilibrium and non-equilibrium segregation, platinum, platinum alloys
\end{abstract}

\section{INTRODUCTION}

The presence of chemical elements - impurities in the platinum metals and alloys is related to the composition of the starting mineral raw materials as well as the technological processes for their preparation, processing and exploitation in the industrial conditions [1-3].

The presence of impurities in the platinum metals and alloys has a major impact on their physical and mechanical properties. Due to this reason, the purity of platinum metals and alloys is one of their key characteristics [4-6].

Depending on the content and distribution of impurities in metal, their interaction also changes. With increasing the content of impurities, a probability of brittle fracture of metals during heating increases. However, technological and exploitation properties of platinum metals and alloys can be significantly modified in the presence of very small amounts of impurities (within hundredths and thousandths of percent). The risk of brittle fracture is so much higher if the increase of content of impurities does not occur in the entire volume of metal, but only in some of its parts $[7,8]$.

Local concentration of impurities in the inter-crystal zone or boundaries within the crystal can be several times higher than the average concentrations in a volu-me of metal. Such local accumulation of impurities in

\footnotetext{
* Mining and Metallurgy Institute Bor, Zeleni bulevar 33, Bor, Serbia

** This work is the results of the Project TR 34029 "Development the Technologies for Production the Pd Catalyst - Catcher for Reduction the Losses of Platinum in High Temperature Catalysis Processes", funded by the Ministry of Education, Science and Technological Development of the Republic of Serbia, in the period from 2011 to 2015.
} 
the metal can be the result of equilibrium or non-equilibrium segregation, as well as the presence of foreign inclusions [9].

Equilibrium segregation of impurities as a rule occupies the area of one to ten nanometers, although in most cases the enrichment of impurities is limited by a monolayer segregation of atoms equal to or slightly greater than the inter-granular zone width 2-3 atomic layers [10]. Equilibrium segregation occurs as a result of diffusion of impurities to the grain boundaries with formation of a concentration gradient.

Non-equilibrium segregation of impurities takes, as a rule, the area of ten microme ters and is generated in the process of metal crystallization or in solid solution as a result of the interaction the impurities with vacancies with formation the pair of vacancyinterstitial atom.

\section{EXPERIMENTAL TECHNIQUE}

Platinum, rhodium and palladium for production the alloys are obtained as a byproduct within the production of electrolytic copper of RTB, Serbia. The required purity is achieved by the additional refining. Composition of tested alloys is listed in Table 1 .

Table 1 Content of alloying elements in tested samples (mass \%)

\begin{tabular}{|c|c|c|c|c|}
\hline Alloy & $\begin{array}{c}\text { Rh } \\
(\text { mass\% })\end{array}$ & $\begin{array}{c}\text { Pd } \\
(\text { mass \% })\end{array}$ & $\begin{array}{c}\text { Ir } \\
(\text { mass \% })\end{array}$ & $\begin{array}{c}\text { Au } \\
(\mathbf{m a s s} \%)\end{array}$ \\
\hline PtRh7 & 7 & - & - & - \\
\hline PtRh25 & 25 & - & - & - \\
\hline PtIr4 & - & - & 4 & - \\
\hline PtRh20Pd10Ir0,1Au0,1 & 20 & 10 & 0.1 & 0.1 \\
\hline
\end{tabular}

Melting of samples was carried out in the medium-frequency induction furnace. Annealing of samples was carried out in the electric furnace type LP08.

To test the mechanical properties of samples at high temperatures, a universal apparatus for tension testing of materials at high temperature, manufacturer Karl Frank, type 81221.

Chemical analysis of the materials for samples was performed in the atomic absorption spectrophotometer.

\section{RESULTS AND DISCUSSION}

Equilibrium segregation of impurities increases linearly with increasing time and temperature warming, with great absorption thereof. The most common is for systems with low solubility of impurities in the crystal lattice of metal-base, as well as in large differences in atomic diameters of impurities and base. In literature is known a dependence of inter-granular zone enriched with impurities from the solubility limit thereof in solid solution. For many studied phase systems, based on $\mathrm{Fe}, \mathrm{Ni}$ and $\mathrm{Cu}$, the enriched space with impurities is as large as limit of their solubility is lower. With decrease of solubility limit of the impurities to $1 \times 10^{-3} \%$ (at.), their concentration in the inter-crystal zone of metal-base may reach $10 \%$ (at.), i.e. it can be 10,000 times higher than the volume of alloys [11-15].

Based on the results of solubility of impurities in platinum, it can be assumed that practically insoluble or slightly soluble impurities like $\mathrm{Ba}, \mathrm{P}, \mathrm{As}, \mathrm{Si}, \mathrm{Bi}$ and $\mathrm{Pb}$ show a high tendency to the formation of equilibrium segregations, while, for example, $\mathrm{Fe}, \mathrm{Ni}$, $\mathrm{Cu}, \mathrm{Ag}, \mathrm{Mg} \mathrm{Zn}, \mathrm{Al}$, and $\mathrm{Sb}$ form with platinum a steady stream of solid solutions.

Equilibrium segregation of impurities leads to decrease in strain energy of the crystal lattice in the zone of their existence, while reducing the Gibbs energy of intergranular limits [16-22]. 
The impurities that accumulate at the grain boundaries can react with each other and lead to an increase or decrease in segregation of this or any other element. In the first case, with the same sign of the atomic range of disagreement between the two particles in relation to the metal - bas , the intercrystalline zone will be more enriched with atoms of impurity atoms that has a larger range of disagreement. In the latter case, at different sign of atomic disagreement and equal concentrations of two impurities there is formation of of complex atoms of these impurities and equilibrium segregation is weak.

Segregation is stronger in the case that impurities that are adsorbed on the surface of crystals have the same sign and similar values of the range of discrepancies.

In this way, it can be expected that in cases where the removal of impurities from the alloy is very difficult, their harmful effect can be minimized by introduction less harmful impurity or impurities with the opposite sign of the discrepancy range.

On the basis of the atomic diameter of platinum that is $0.139 \mathrm{~nm}$, it is possible to form a range of deviations of the atomic diameters of impurities.

Size range of deviations $(\Delta r)$ of the atomic diameters of platinum and impurities, in the case where diameter of platinum is higher $(+\Delta r)$ or less $(-\Delta r)$ in relation to the diameters of impurities, is given in Table 2 .

Table 2 Size range of deviations $(\Delta r)$ for impurities

\begin{tabular}{|c|c|c|c|}
\hline Element & $\mathbf{\Delta r}, \mathbf{n m}$ & Element & $\mathbf{\Delta r}, \mathbf{n m}$ \\
\hline $\mathrm{Zn}$ & +0.006 & $\mathrm{As}$ & +0.014 \\
\hline $\mathrm{Si}$ & -0.021 & $\mathrm{Sn}$ & -0.012 \\
\hline $\mathrm{P}$ & -0.021 & $\mathrm{Mg}$ & -0.021 \\
\hline $\mathrm{Cu}$ & +0.011 & $\mathrm{Zr}$ & -0.020 \\
\hline $\mathrm{Fe}$ & +0.015 & $\mathrm{Sb}$ & +0.012 \\
\hline $\mathrm{Cr}$ & +0.014 & $\mathrm{~Pb}$ & -0.036 \\
\hline $\mathrm{Co}$ & +0.014 & $\mathrm{Y}$ & -0.039 \\
\hline $\mathrm{Ni}$ & +0.014 & $\mathrm{Bi}$ & -0.016 \\
\hline $\mathrm{Al}$ & -0.004 & $\mathrm{Ca}$ & -0.058 \\
\hline $\mathrm{Ag}$ & -0.005 & $\mathrm{Ba}$ & -0.078 \\
\hline $\mathrm{Ti}$ & -0.007 & $\mathrm{~K}$ & -0.088 \\
\hline
\end{tabular}

On the basis of the values shown in Table 1 , it can be concluded that $\mathrm{Zr}$ decreases the equilibrium segregation and negative impact of impurities, such as $\mathrm{Si}$ and $\mathrm{P}$ in tested platinum alloys. Bismuth can somewhat neutralize the negative impact and accumulation of impurities such as $\mathrm{Fe}, \mathrm{Cu}$, $\mathrm{Cr}, \mathrm{Co}, \mathrm{As}$ and $\mathrm{Ni}$.

Also, the presence of $\mathrm{Ca}, \mathrm{Ba}$ and $\mathrm{K}$ in platinum alloys can be neutralized with different impurities with the sign of deviation range, such as $\mathrm{Zn}, \mathrm{Cu}$, As, $\mathrm{Cr}, \mathrm{Co}, \mathrm{Ni}, \mathrm{Mg}$.

The most severe is the form of presence the impurities with the approximate values of deviation range, and of the same sign, for example, $\mathrm{Al}$ and $\mathrm{Ag}$, as one pair and $\mathrm{Sb}$ and $\mathrm{Zn}$ as the second pair. In these cases, the probability of equilibrium segregation of each pair of impurities increases as well as their negative impact on the technological and exploitation properties of platinum alloys.

However, in practical terms, it is difficult to predict and even harder to manage the equilibrium segregation of impurities in platinum alloys.

In real terms of formation the equilibrium segregation, ten of impurities can take 
part, and that process may depend heavily on their mutual effects, the effect with the metal - base and alloying element with simultaneous temperature dependence - the time factor

The question of formation the nonequilibrium segregations of impurities in solid solution with formation the pair of vacancy - interstitial atom is not sufficiently clarified. It is believed that during cooling the heated metal in the crystal lattice, a large number of vacancies occurs which diffuse to the grain boundaries in a pair with atom impurities. At the grain boundary, the pair of vacancy - interstitial atoms bump into each other to form an accumulation of atom impurities. At slower cooling of heated metal, the probability of development is more likely for the process and the area of nonequilibrium segregation of impurities becomes significant. If the higher the temperature of metal during cooling, the more significant is formation the pair of vacancy - interstitial atom, which segregate to the grain boundaries, increasing the non-equilibrium segregation of impurities, as shown in Figure 1.

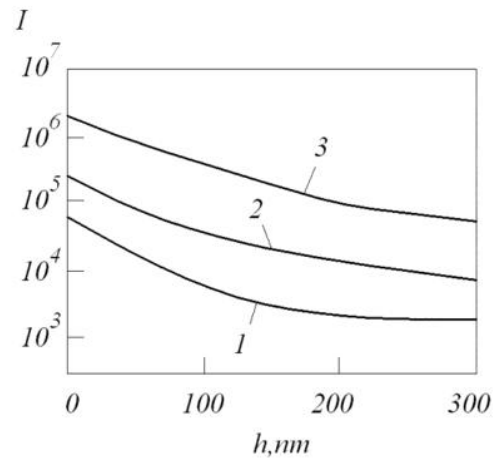

Figure 1 Profile of Al distribution along the thickness of sample composition PtRh20Pd10Ir0,1Au0,1 in non-annealed condition (1), after annealing in the air at $1,400^{\circ} \mathrm{C}, 50 \mathrm{~h}$, away from the border (2) and at the grain boundaries (3) $\left(j=100 \mu \mathrm{A} / \mathrm{cm}^{2}, \mathrm{PO}_{2}=10^{-3} \mathrm{~Pa}\right.$, I-size of the output secondary ions)

Segregation of aluminum was observed during the study of secondary ions on microanalyzer, the investigated alloys using mass spectrometric method (concentration of impurities was $10^{-3}$ to $10^{-5} \%$. Based on the value of output of secondary ions (I), it can be concluded that with distance from the sample surface of non-annealed alloy, the $\mathrm{Al}$ concentration decreases. After annealing the platinum alloy at $1.400^{\circ} \mathrm{C}$ for $50 \mathrm{~h}$ in the air, the concentration of $\mathrm{Al}$ in the surface layers of sample, in the grain boundaries, is twice as higher than that of the grain.

Comparatively with equilibrium and non-equilibrium segregation of impurities in the platinum alloys, the groups of impurities were observed in the form of foreign inclusions. In these inclusions, the impurities are, as a rule, in the form of solid compounds, usually in the form of oxides. Oxide parti cles get into the alloy, for example, in the process of melting in ceramic pots or arise in the form of silicate inclusions in the warming process. The size of these inclusions reaches a hundredth of micrometer.

Based on numerous experiments, the possibility of formation of these inclusions was confirmed in the platinum alloys. The investigation of the alloy PtRh20Pd10Ir0,1 Au0, 1 by the electron probe (after creeping at $1,400^{\circ} \mathrm{C}$, at load of $5 \mathrm{MPa}$ ) has studied the foreign inclusions arranged along grain boundaries and within grains.

Along the grain boundaries, the inclusions reach the size of 40-50 microns and contain $\mathrm{Si}$ and $\mathrm{Ti}$. Large inclusions of copper were discovered inside the grain. Small number of inclusions (up to 10 microns) based on $\mathrm{Al}$ and $\mathrm{Si}$ occur both in the grain boundaries and within the grains themselves. 
The number of small inclusions containing $\mathrm{Mg}, \mathrm{Zn}, \mathrm{Ni}$ and $\mathrm{Cr}$ is negligible. The inclusions of complex composition, type of $\mathrm{Al}-$ $\mathrm{Fe}-\mathrm{Ti}, \mathrm{Si}-\mathrm{Cr}-\mathrm{Sn}$ and $\mathrm{Pb}-\mathrm{Sn}$, are also present.

Impurities such as $\mathrm{Al}, \mathrm{Mg}, \mathrm{Si}$, and $\mathrm{Fe}$, present in platinum alloys, after heating in the air $\left(1400^{\circ} \mathrm{C}, 50 \mathrm{~h}\right)$, are found primarily in the oxide form, while after annealing in vacuum $\left(1400^{\circ} \mathrm{C}, 2 \mathrm{~h}\right)$ are registered in elemental form.
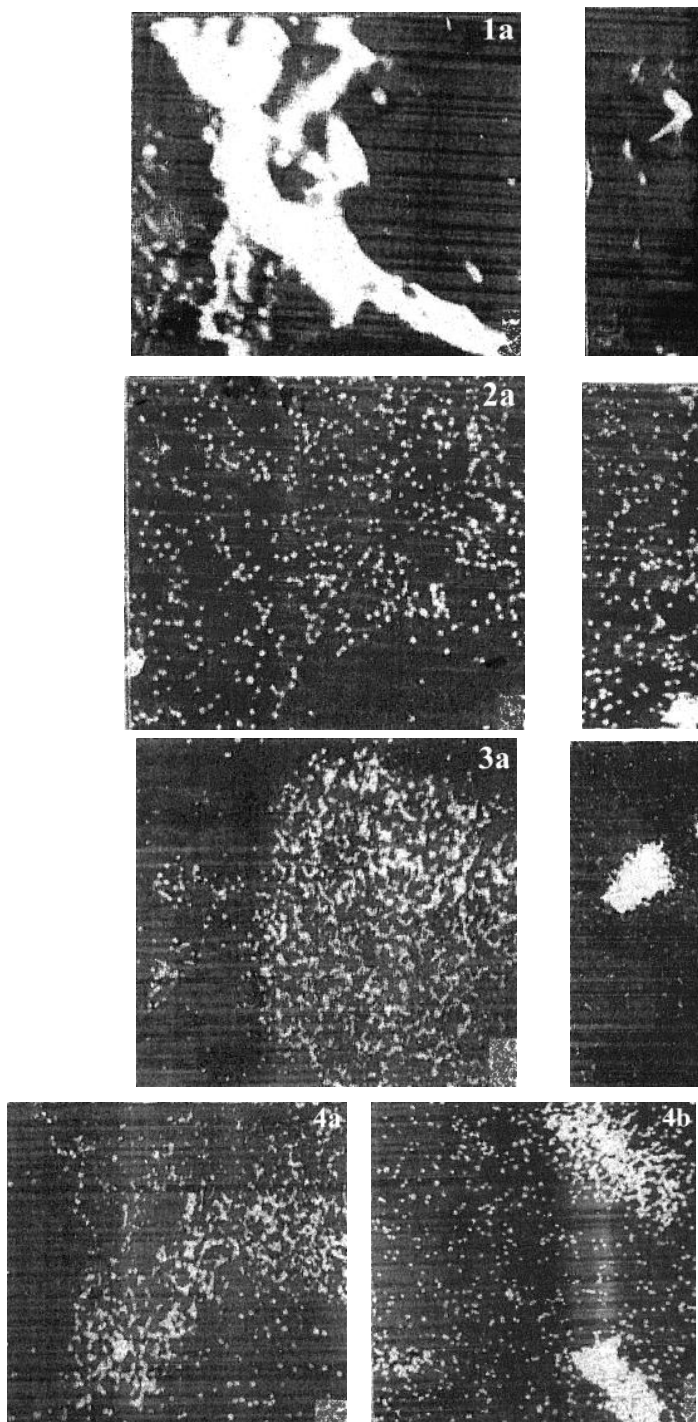

Figure 2 Standard view the area of the sample composition PtRh2OPd10Ir0,1Au0,1 with inclusions of impurities with the secondary electrons $(1 a)$ and $(1 b)$, at the characteristic X-ray radiation FeKa (2a),

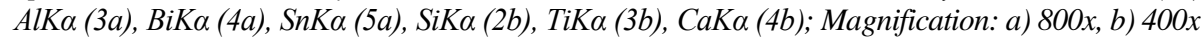

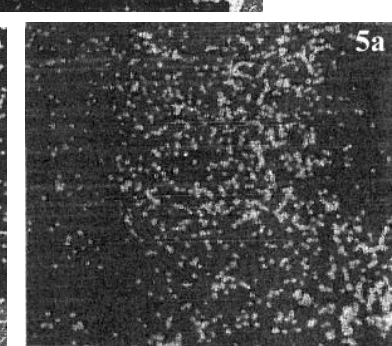

By investigation the alloy of composition PtRh20Pd10Ir0,1Au0,1 it was shown that foreign inclusions contain a tenth of the percentage of $\mathrm{S}, \mathrm{C}, \mathrm{P}$ and $\mathrm{Pb}$ and other harmful impurities [23].

Figure 2 gives the standard view of the area of the sample composition PtRh20Pd10 Ir0,1Au0,1 with inclusions of impurities both on the grain boundaries and within the grains in characteristic radiation.
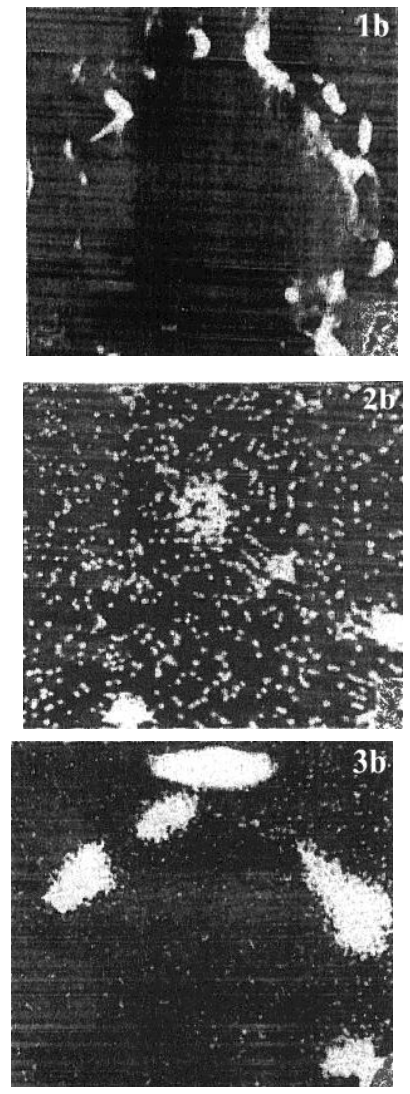
It is obvious that, in the area where the inclusions enriched with $\mathrm{Fe}, \mathrm{Al}, \mathrm{Si}, \mathrm{Ca}, \mathrm{Ti}$, $\mathrm{Bi}$ and $\mathrm{Pb}$ are present, the local concentration of impurities ranges from $5-40 \%$.
Also, it is noticed the probability of presence in different ways resulting inclusions enriched with $\mathrm{Si}, \mathrm{Ca}, \mathrm{Al}, \mathrm{Ag}$, As and $\mathrm{Pb}$ (Figures 3-6).

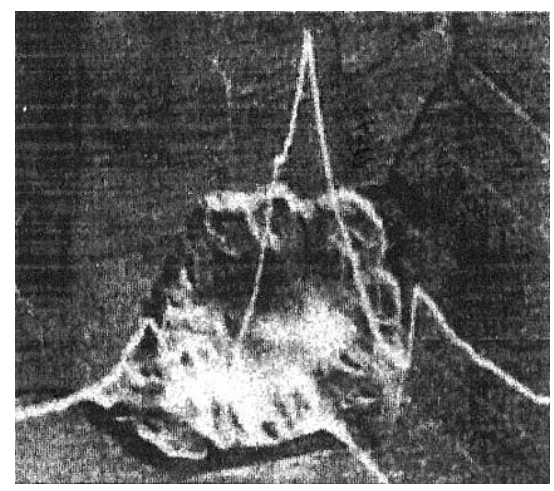

Figure 3 Standard view the area of the sample composition with PtRh7 inclusions and line distribution of Si in it at Ka radiation

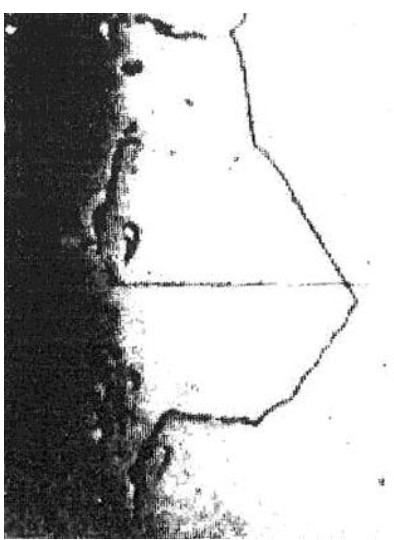

a

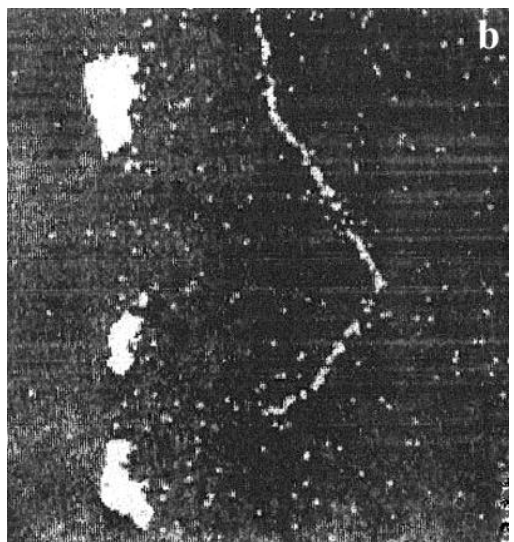

Figure 4 Area of destruction the sample PtRh25 with inclusions, with content of Ag with the secondary electrons (a) and in X-ray separation of $A g K \alpha$ (b) (Magnification 360x)

a

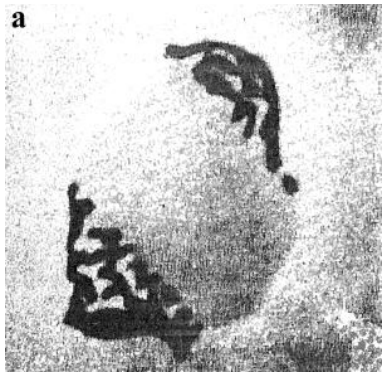

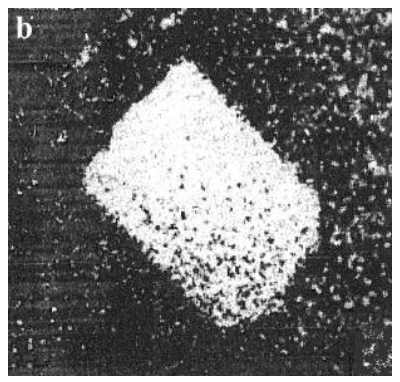

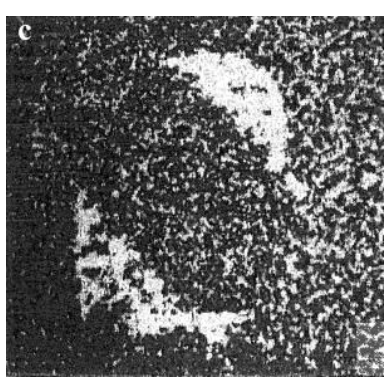

Figure 5 View a part of platinum sample with the inclusion of secondary electrons a) and in the X-ray PbKa separation (b) and AsKa (c), (Magnification 720x) 

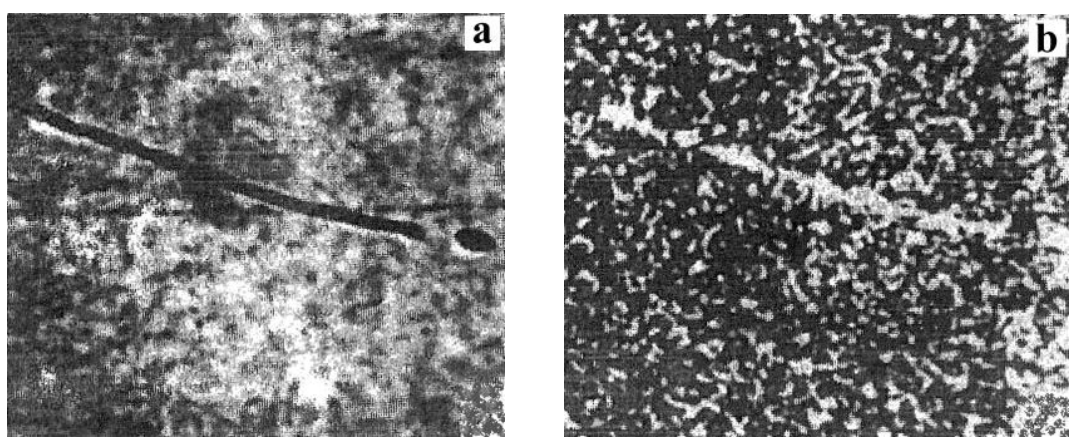

Figure 6 View a part of alloy sample PtIr4 with the inclusions containing Pb, with secondary electrons (a) and in the X-ray PbKa separation (b) (magnification 850x)

In most cases, the foreign inclusions in normal light microscope, as shown in the platinum alloy can be seen under the Figure 7.

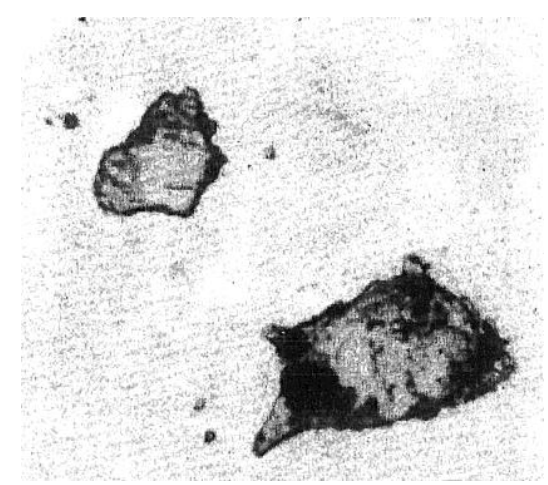

Figure 7 Inclusion in the alloy PtRh20Pd10Ir0,1Au0,1 seen under the light microscope

In investigation the microstructure of in Figure 8, the characteristic glassy separapure platinum after creeping at $1350^{\circ} \mathrm{C}$, at tions could be observed. stress of $13 \mathrm{MPa}$ for $10 \mathrm{~min}$ as shown

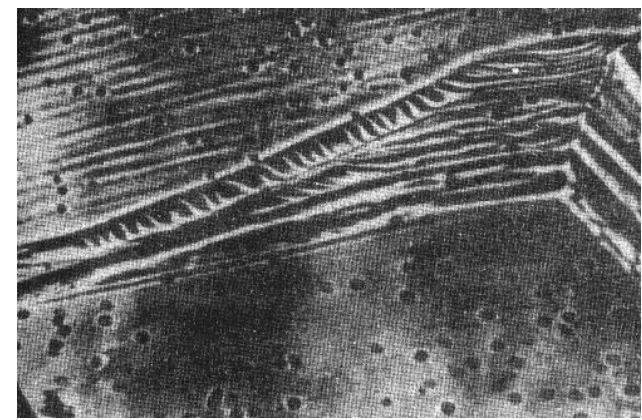

Figure 8 Microstructure of pure platinum after creeping at $1350^{\circ} \mathrm{C}$, at stress of 13 MPa for 10 min (magnification 300x) 
Similar separations were the subject of research the alloy PtIr4, where it was observed that at temperature higher than $1300^{\circ} \mathrm{C}$, the sample surface is covered with many small droplets of liquid, which gradually pour forming a large transparent drops, as shown in Figure 9 .
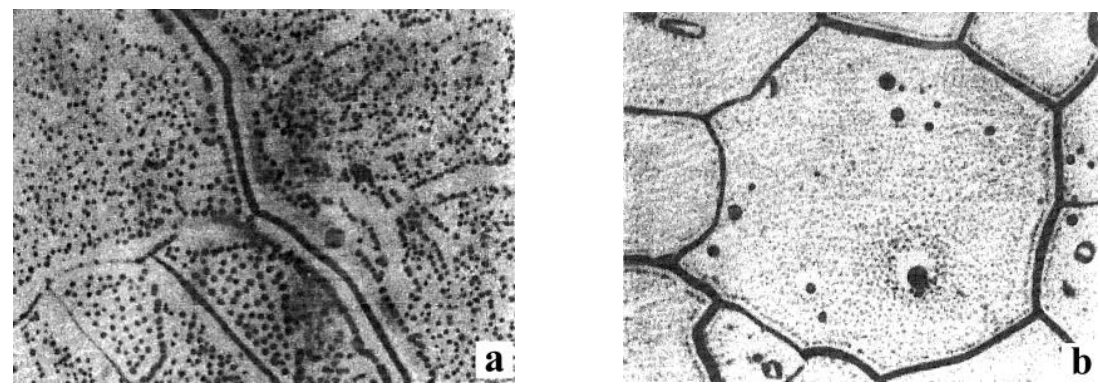

Figure 9 Surface of the alloy PtIr4 with formation of silicate drops after annealing at $1400^{\circ} \mathrm{C}$. a) 4 h, magnification 500x; b) 300 h, magnification 100x

The limits and sub-limits occur at the same time as the zone of separation and further removal of liquid. The separated

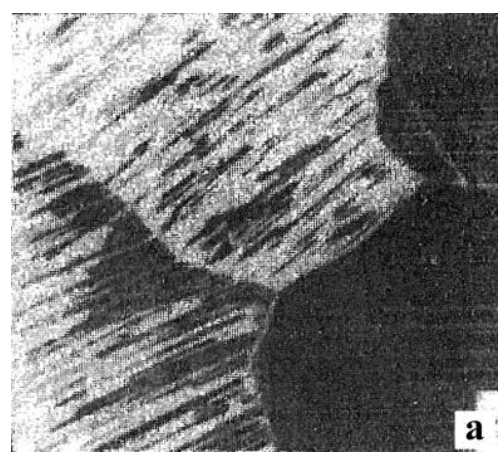

liquid makes it difficult sliding over the plane (111) within the grain, as shown in Figure 10.

Figure 10 Lines of sliding within the grain formed on platinum surface at heating in the air: a) up to $1.300^{\circ} \mathrm{C}$, magnification $200 x$; b) over $1300^{\circ} \mathrm{C}$, magnification $500 x$

If the rate of metal heating up to $1300^{\circ} \mathrm{C}$ is rather large, making slipping lines is unlikely. Only in the exceptional uncontrolled cases on the surface of platinum, a small amount of slipping lines of liquid phase, as shown in Figure $10 \mathrm{~b}$, can be observed inside the grain at the same time.

The absence of slipping lines in the presence of liquids (droplets) on the metal surface is associated with it, that all drops are

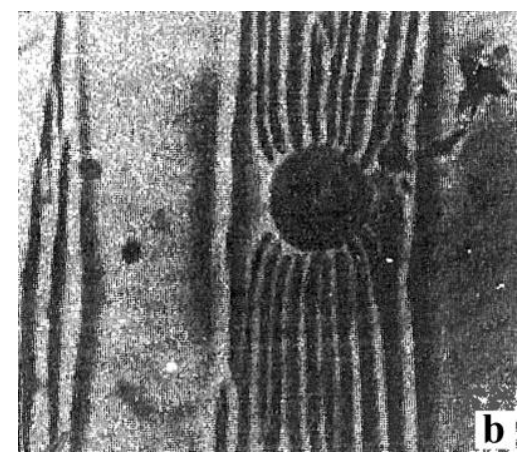

united in a thin film of liquid which prevents the formation of a layer of adsorbed oxygen, and thus the creation of slip lines. Hardened drops of liquid did not react with hydrochloric or nitric acid, but they are excellent diluted in fluorohydrochloric acid. Microanalysis of hardened drops showed the presence of $8 \% \mathrm{Si} ; 10 \% \mathrm{Al} ; 10 \% \mathrm{Ca} ; 0.1 \% \mathrm{Ni} ; 0.1 \%$ $\mathrm{Fe} ; 0.1 \% \mathrm{Mn}$, and $0.1 \% \mathrm{Mg}$. In addition to these elements, $\mathrm{Pb}$ and $\mathrm{Na}$ were present. 
Spectral analysis showed that platinum heating for a period of $800 \mathrm{~h}$ results into a gradual reduction of content of impurities such as $\mathrm{Si}, \mathrm{Fe}, \mathrm{Ni}, \mathrm{Ca}$ and $\mathrm{Mg}$. Formation of liquid silicate phase is associated with reduction in creeping resistance of platinum and its alloys at content of some of these impurities, as the intermediate layer of molten silicates on the planes grain boundaries probably accelerates sliding.

\section{CONCLUSION}

Based on the previous results of research, it can be concluded the following:

In real conditions of formation the equilibrium segregation, ten of impurities can take part and the process is very depend on their mutual effects, the effect with the metal - base and alloying elements with simultaneous dependence temperature - time factor.

If the higher metal temperature in cooling, therefore, the creation of a pair vacancy-interstitial atom is much more important that diffuses to the grain boundaries, increasing the non-equilibrium segregation of impurities.

Along with the equilibrium and nonequilibrium segregation of impurities in the platinum alloys, the groups of impurities were observed in the form of foreign inclusions. In these inclusions, the impurities are in the form of solid compounds, usually in oxide form. Oxide particles enter the alloy in the melting process in ceramic pots or arise in the form of silicate inclusions in the heating process. The size of these inclusions reaches a hundredth part of a micrometer.

The impurities such as $\mathrm{Al}, \mathrm{Mg}, \mathrm{Si}$, and $\mathrm{Fe}$, present in the platinum alloys, after heating in the air $\left(1400^{\circ} \mathrm{C}, 50 \mathrm{~h}\right)$, are in the oxide form, whereas after annealing in vacuum $\left(1400^{\circ} \mathrm{C}, 2 \mathrm{~h}\right)$ are registered in the elemental form.

The investigation the alloy of composition PtRh20Pd10Ir0,1Au0,1 has shown that foreign inclusions contain a tenth of the percentage of $\mathrm{S}, \mathrm{C}, \mathrm{P}$ and $\mathrm{Pb}$, and other harmful impurities.
Segregation of impurities in the platinum alloys is conditioned by the nature of impurities, their concentration, distribution in the volume of metal, interaction with the basic and alloying components as well as the temperature - time factor. It is possible to expect that as the result of interaction of harmful impurities with the platinum metals that enter the composition of the alloy, the reductions of a high-temperature resistance of the alloy and increase the possibility of brittle fracture at high temperatures are formed.

\section{REFERENCES}

[1] H. Gavin, Platinum Met. Rev. 54 (2010) 166.

[2] E. Preston, Platinum Met. Rev. 4 (1960) 48.

[3] D. F. Lupton, J. Merker, B. Fischer, R. Völkl, 24 ${ }^{\text {th }}$ International Precious Metals Cconference, Williamsburg, Virginia, USA, 1-14 June 2000.

[4] Y. Ning, Z. Yang, H. Zhao, Platinum Met. Rev.4 (1996) 80.

[5] N. Yuantao, Y. Zhengfen, Platinum Met. Rev. 43 (1999) 62.

[6] B. Trumić, D. Stanković, V. Trujić, J. Min. Metall., Sect. B 45 (1) B (2009) $79-87$.

[7] B. Wu, G. Liu, , Platinum Met. Rev. 41 (1997) 81.

[8] M. Funabikia, T. Yamadaa, K. Kayanoa, Catal. Today 10 (1991) 33.

[9] T. Biggs, S.S. Taylor, E. Van der Lingen, Platinum Met. Rev. 49 (2005) 2.

[10] John C. Wright, Platinum Metals Rev., 2002, 46 (2), 66.

[11] T. Biggs, M. B. Cortie, M. J. Witcomb, L. A. Cornish, Platinum Metals Rev., 2003, 47, (4), 142.

[12] T. Biggs, M.J. Witcomb, L.A. Cornish, Materials Science and Engineering A273-275 (1999) 204.

[13] F. Xiao, F. Zhao, D. Mei, Z. Mo, B. Zeng, Biosens. Bioelectron. 24 (2009) 3481 . 
[14] K. T. Jacob, S. Priya, and Y. Waseda, Metall. Mater. Trans. A 29A (1998) 1545.

[15] G. Dereli, T. Cagin, M. Uludogan, M. Tomak, Philos. Mag. Lett. 75 (4) (1997) 209.

[16] P. Battaini, Platinum Met. Rev. 55 (2011) 74

[17] J. Luyten, J. De Keyzer, P. Wollants, C. Creemers, Calphad 33 (2009) 370.

[18] B. Trumic, L. Gomidželovic, S. Marjanovic, V. Krstic, A. Ivanovic, S. Dimitrijevic, Pt - Materials Testing, 55 (2013) 38.

[19] Ритвин, Е. И., Медовој, Л.А.: Влиание физико-химическој следи на жаропрочност мераллических материалов, Москва, Наука, 1974

[20] Савицкиј, Е. М., Полјакова В. П., Горина, Н. Б., Рошан, Н. Р.: Металоведение платинових металов, Москва, Металургија, 1975.

[21] Захаров, М. В., Захаров, А. М.: Жаропрочние сплави, Москва, Металургија, 1983.

[22] Ритвин, Е. И.,: Жаропрочност платинових сплавоажв, Москва, Металургија, 1987.

[23] B. Trumić, L. Gomidželović, M. Bugarin, Mining and Metallurgy Engineering Bor, 1/2015, p. 141-148. 


\begin{tabular}{ll}
\hline \hline INSTITUT ZA RUDARSTVO I METALURGIJU BOR & ISSN: 2334-8836 (Štampano izdanje) \\
UDK: 622 & ISSN: 2406-1395 (Online) \\
\hline \hline
\end{tabular}

\title{
SEGREGACIJA NEČISTOĆA U PLATINI I LEGURAMA NA BAZI PLATINE***
}

\begin{abstract}
Izvod
U radu su predstavljeni rezultati ispitivanja nastanka ravnotežnih i neravnotežnih segregacija nečistoća kako u čistoj, tako i u legurama platine. Pokazano je da segregacije jačaju u slučaju kada nečistoće, apsorbovane na površini kristala imaju isti znak ili pak slične vrednosti opsega odstupanja u odnosu na čistu platinu. Ravnotežna segregacija javlja se kao rezultat difuzije nečistoća ka granicama zrna uz stvaranje koncentracionog gradijenta.

Neravnotežna segregacija nečistoća zauzima oblast veličine desetak mikrometara i nastaje u procesu kristalizacije metala ili u čvrstom rastvoru kao rezultat uzajamnog dejstva nečistoća s vakancijama uz obrazovanje para vakancija-intersticijski atom.

Segregacija nečistoća u platinskim legurama uslovljena je prirodom nečistoća, njihovom koncentracijom, raspodelom u zapremini metala, uzajamnim dejstvom sa osnovnim $i$ legirnim komponentama, kao i temperaturno - vremenskim faktorom.

Uporedo sa ravnotežnom i neravnotežnom segregacijom nečistoća u platinskim legurama primećene su skupine nečistoća u obliku stranih uključaka.
\end{abstract}

Ključne reči: nečistoće, ravnotežna i neravnotežna segregacija, platina, legure platine

\section{UVOD}

Prisustvo hemijskih elemenata-nečistoća u platinskim metalima i legurama povezano je sa sastavom polaznih rudnih sirovina kao i sa tehnološkim operacijama njihovog dobijanja, prerade i eksploatacije u industrijskim uslovima [1-3].

Prisustvo nečistoća u platinskim metalima i legurama ima veliki uticaj na njihova fizička i mehanička svojstva. Iz tog razloga, čistoća platinskih metala i legura jedna je od njihovih ključnih karakteristika [4-6].

U zavisnosti od sadržaja i rasporeda nečistoća u metalu menja se i njihovo međusobno dejstvo. Sa povećanjem sadržaja nečistoća verovatnoća krtog preloma metala pri zagrevanju raste. Međutim, tehnološka i eksploataciona svojstva platinskih metala i legura mogu se bitno izmeniti u prisustvu veoma malih količina nečistoća (u granicama stotih i hiljaditih delova procenata). Opasnost od krtog preloma je utoliko veća, ukoliko do povećanja sadržaja nečistoća ne dolazi u celoj zapremini metala, već samo u pojedinim njegovim delovima $[7,8]$.

Lokalna koncentracija nečistoća u međukristalnoj zoni ili granicama unutar kristala može biti i nekoliko puta viša od srednje koncentracije u zapremini metala. Takvo lokalno nagomilavanje nečistoća u metalu može biti rezultat ravnotežne ili

\footnotetext{
* Institut za rudarstvo i metalurgiju Bor, Zeleni bulevar 33, Bor, Srbija

** Ovaj rad je nastao kao rezultat projekta TR 34029 ,"Razvoj tehnologije proizvodnje Pd katalizatorahvatača za smanjenje gubitaka platine u visoko temperaturnim procesima katalize", finansiran od strane Ministarstva prosvete, nauke i tehnološkog razvoja Republike Srbije, u periodu 2011.-2015.
} 
neravnotežne segregacije, kao i prisustva stranih uključaka [9].

Ravnotežna segregacija nečistoća zauzima po pravilu područje od jednog do desetak nanometara, premda u većini slučajeva obogaćenje nečistoćama ograničeno je monoslojnom segregacijom atoma jednakom ili neznatno većom od međukristalne zone širine 2-3 atomska sloja [10]. Ravnotežna segregacija javlja se kao rezultat difuzije nečistoća ka granicama zrna uz stvaranje koncentracionog gradijenta.

Neravnotežna segregacija nečistoća zauzima, po pravilu, oblast veličine desetak mikrometara i nastaje u procesu kristalizacije metala ili u čvrstom rastvoru kao rezultat uzajamnog dejstva nečistoća $\mathrm{s}$ vakancijama uz obrazovanje para vakancijaintersticijski atom.

\section{EKSPERIMENTALNA TEHNIKA}

Platina, rodijum i paladijum za izradu legura su dobijeni kao sporedan proizvod $u$ okviru proizvodnje elektrolitičkog bakra RTB, Srbija. Dodatnom rafinacijom postignuta je neophodna čistoća. Sastav ispitivanih legura je naveden u tabeli 1 .

Tabela 1. Sadržaj legirnih elemenata u ispitivanim uzorcima (maseni \%)

\begin{tabular}{|l|c|c|c|c|}
\hline \multicolumn{1}{|c|}{ Legura } & $\begin{array}{c}\text { Rh } \\
(\text { mas.\% })\end{array}$ & $\begin{array}{c}\text { Pd } \\
\text { (mas.\%) }\end{array}$ & $\begin{array}{c}\text { Ir } \\
\text { (mas.\% })\end{array}$ & $\begin{array}{c}\text { Au } \\
(\text { mas. \% })\end{array}$ \\
\hline PtRh7 & 7 & - & - & - \\
\hline PtRh25 & 25 & - & - & - \\
\hline PtIr4 & - & - & 4 & - \\
\hline PtRh20Pd10Ir0,1Au0,1 & 20 & 10 & 0,1 & 0,1 \\
\hline
\end{tabular}

Topljenje uzoraka vršeno je u srednjefrekventnoj indukcionoj peći. Žarenje uzoraka vršeno je u elektrootpornoj peći tipa LP08.

Za ispitivanje mehaničkih karakteristika uzoraka na visokim temperaturama korišćen je univerzalni aparat za ispitivanje materijala zatezanjem na viskoim temperaturama, proizvođača Karl Frank, tip 81221.

Hemijska analiza materijala za uzorke izvršena je na atomskom apsorpcionom spektrofotometru.

\section{REZULTATI I DISKUSIJA}

Ravnotežna segregacija nečistoća linearno raste sa povećanjem vremena i temperature zagrevanja, uz veliku apsorbciju istih. Najzastupljenija je kod sistema s malom rastvorljivošću nečistoća u kristalnoj rešetki metala-osnove, kao i pri velikim razlikama u atomskim prečnicima nečistoća $\mathrm{i}$ osnove. $U$ literaturi poznata je zavisnost veličine međukristalne zone obogaćene nečistoćama od granice rastvorljivosti istih $\mathrm{u}$ čvrstom rastvoru. Za mnoge proučavane fazne sisteme na bazi $\mathrm{Fe}, \mathrm{Ni}$ i $\mathrm{Cu}$ prostor obogaćen nečistoćama je utoliko veći, ukoliko je manja granica njihove rastvorljivosti. Sa smanjenjem granice rastvorljivosti nečistoća do $1 \times 10^{-3} \%$ (at.), njihova koncentracija u međukristalnoj zoni metala-osnove može dostići $10 \%$ (at.), tj. može 10.000 puta biti veća u odnosu na zapreminu legure [11-15].

$\mathrm{Na}$ osnovu rezultata rastvorljivosti nečistoća u platini, može se pretpostaviti da praktično nerastvorne ili malo rastvorne nečistoće poput $\mathrm{Ba}, \mathrm{P}, \mathrm{As}, \mathrm{Si}, \mathrm{Bi}$ i $\mathrm{Pb}$ pokazuju veliku sklonost ka obrazovanju ravnotežnih segregacija, dok na primer Fe, $\mathrm{Ni}, \mathrm{Cu}, \mathrm{Ag}, \mathrm{Mg}, \mathrm{Zn}, \mathrm{Al}$ i Sb obrazuju s platinom neprekidan niz čvrstih rastvora.

Ravnotežna segregacija nečistoća dovodi do smanjenja energije deformacije kristalne rešetke u zoni njihovog postojanja, uz istovremeno smanjenje Gibsove energije međuzrnih granica [16-22].

Nečistoće koje se nagomilavaju na granicama zrna mogu međusobno reagovati i dovesti do porasta ili smanjenja segregacije 
tog ili nekog drugog elementa. U prvom slučaju, pri istom znaku atomskog opsega neslaganja dvaju primesa u odnosu na metal - osnovu, međukristalna zona biće obogaćenija atomima one nečistoće koja ima veći opseg neslaganja. U drugom slučaju, pri različitom znaku atomskog neslaganja i jednakim koncentracijama dvaju primesa dolazi do obrazovanja kompleksnih atoma tih nečistoća i ravnotežna segregacija slabi.

Segregacija jača u slučaju kada nečistoće koje se apsorbuju na površini kristala imaju isti znak i slične vrednosti opsega odstupanja.
Na taj način može se očekivati da u slučajevima kada je odstranjivanje štetnih primesa iz legure veoma otežano, njihov štetni uticaj može biti sveden na minimum i uvođenjem manje štetne nečistoće ili nečistoće sa suprotnim znakom opsega odstupanja.

$\mathrm{Na}$ osnovu atomskog prečnika platine koji iznosi $0,139 \mathrm{~nm}$, moguće je formirati niz opsega odstupanja atomskih prečnika nečistoća.

Veličina opsega odstupanja $(\Delta r)$ atomskih prečnika platine i nečistoća, u slučaju kada je prečnik platine veći $(+\Delta r)$ ili manji $(-\Delta r) \mathrm{u}$ onosu na prečnike nečistoća dat je $\mathrm{u}$ tabeli 2.

Tabela 2. Veličina opsega odstupanja $(\Delta r)$ za nečistoće

\begin{tabular}{|c|c|c|c|}
\hline Element & $\mathbf{\Delta r}, \mathbf{n m}$ & Element & $\mathbf{\Delta r}, \mathbf{n m}$ \\
\hline $\mathrm{Zn}$ & $+0,006$ & $\mathrm{As}$ & $+0,014$ \\
\hline $\mathrm{Si}$ & $-0,021$ & $\mathrm{Sn}$ & $-0,012$ \\
\hline $\mathrm{P}$ & $-0,021$ & $\mathrm{Mg}$ & $-0,021$ \\
\hline $\mathrm{Cu}$ & $+0,011$ & $\mathrm{Zr}$ & $-0,020$ \\
\hline $\mathrm{Fe}$ & $+0,015$ & $\mathrm{Sb}$ & $+0,012$ \\
\hline $\mathrm{Cr}$ & $+0,014$ & $\mathrm{~Pb}$ & $-0,036$ \\
\hline $\mathrm{Co}$ & $+0,014$ & $\mathrm{Y}$ & $-0,039$ \\
\hline $\mathrm{Ni}$ & $+0,014$ & $\mathrm{Bi}$ & $-0,016$ \\
\hline $\mathrm{Al}$ & $-0,004$ & $\mathrm{Ca}$ & $-0,058$ \\
\hline $\mathrm{Ag}$ & $-0,005$ & $\mathrm{Ba}$ & $-0,078$ \\
\hline $\mathrm{Ti}$ & $-0,007$ & $\mathrm{~K}$ & -0088 \\
\hline
\end{tabular}

$\mathrm{Na}$ osnovu vrednosti prikazanih u tabeli 1 može se zaključiti da $\mathrm{Zr}$ smanjuje ravnotežnu segregaciju i negativan uticaj nečistoća, kao što su Si, i P u ispitivanim platinskim legurama. Bizmut donekle može neutralizovati negativan uticaj i nagomilavanje nečistoća poput $\mathrm{Fe}, \mathrm{Cu}, \mathrm{Cr}, \mathrm{Co}, \mathrm{As}$ i Ni.

Takođe, prisustvo $\mathrm{Ca}, \mathrm{Ba}$ i $\mathrm{K}$ u platinskim legurama može biti neutralizovano nečistoćama s različitim znakom opsega odstupanja, poput $\mathrm{Zn}, \mathrm{Cu}, \mathrm{As}, \mathrm{Cr}, \mathrm{Co}, \mathrm{Ni}, \mathrm{Mg}$.

Najteži je oblik prisustva nečistoća $s$ približnim vrednostima opsega odstupanja, a istog znaka, na primer $\mathrm{Al}$ i Ag, kao jedan par i Sb i Zn kao drugi par. U tim slučajevima, raste verovatnoća ravnotežne segregacije svakog para nečistoća kao i njihov negativan uticaj na tehnološke i eksploatacione osobine platinskih legura.

Međutim, u praktičnim uslovima teško je prognozirati a još teže upravljati procesom ravnotežne segregacije nečistoća u platinskim legurama.

U realnim uslovima u nastajanju ravnotežne segregacije može uzeti učešće desetak nečistoća i taj proces može jako zavisiti od njhovog međusobnog dejstva, dejstva s metalom - osnovom i legirnim elementima uz istovremenu zavisnost temperaturno - vremenskog faktora.

Pitanje nastanka neravnotežnih segregacija nečistoća u čvrstom rastvoru uz 
obrazovanje para vakancija - intersticijski atom nije dovoljno razjašnjeno. Smatra se da pri hlađenju zagrejanog metala u kristalnoj rešetki nastaje veliki broj vakancija koje difunduju ka granicama zrna u paru $\mathrm{s}$ atomom nečistoća. Na granici zrna par vakancija - intersticijski atom međusobno se sudaraju pri čemu nastaje nagomilavanja atoma nečistoća. Pri sporijem hlađenju zagrejanog metala veća je verovatnoća odvijanja procesa i oblast neravnotežne segregacije nečistoća postaje značajna. Ukoliko je viša temperatura metala pri hlađenju, utoliko je više i značajnije stvaranje para vakancija - intersticijski atom koji difunduje ka granicama zrna, pojačavajući neravnotežnu segregaciju nečistoća, kako je prikazano na slici 1 .

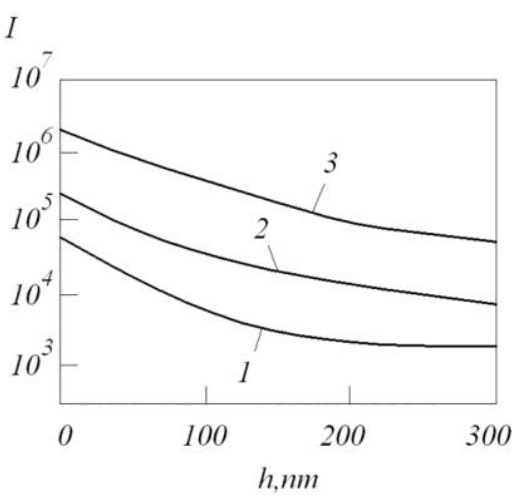

Sl. 1. Profil raspodele Al po debljini uzorka sastava PtRh20Pd10Ir0,1Au0,1 u nežarenom stanju

(1), posle žarenja na vazduhu na $1.400^{\circ} \mathrm{C}, 50 \mathrm{~h}$, dalje od granice (2) i na granicama zrna (3) $\left(j=100 \mu \mathrm{A} / \mathrm{cm}^{2}, \mathrm{PO}_{2}=10^{-3} \mathrm{~Pa}\right.$, I - veličina izlaznih sekundarnih jona)

Segregacija aliminijuma bila je zapažena pri istraživanju sekundarnih jona, na mikroanalizatoru, ispitivane legure metodom masene spektrometrije (koncentracija nečistoća iznosila je $10^{-3}$ do $10^{-5} \%$. Na osnovu vrednosti izlaznih sekundarnih jona (I) može se zaključiti da sa udaljavanjem od površine uzorka neodžarene legure koncentracija $\mathrm{Al}$ se smanjuje. Nakon žarenja platinske legure na $1.400^{\circ} \mathrm{C}$ u trajanju od $50 \mathrm{~h}$ na vazduhu, koncentracija Al u površinskim slojevima uzorka, u granicama zrna, duplo je veća u odnosu na samo zrno.

Uporedo sa ravnotežnom i neravnotežnom segregacijom nečistoća u platinskim legurama primećene su skupine nečistoća $u$ obliku stranih uključaka. U tim uključcima nečistoće se nalaze, po pravilu, u obliku čvrstih jedinjenja, najčešće u obliku oksida. Čestice oksida dospevaju u leguru, na primer, u procesu topljenja u keramičkim loncima ili nastaju u vidu silikatnih uključaka u procesu zagrevanja. Veličina tih uključaka dostiže stoti deo mikrometra.
Na osnovu brojnih eksperimenata potvrđena je mogućnost obrazovanja tih uključa$\mathrm{ka} \mathrm{u}$ platinskim legurama. Istraživanjem legure PtRh20Pd10Ir0,1 Au0,1 elektronskom sondom (nakon puzanja na $1.400^{\circ} \mathrm{C}$, pri opterećenju od $5 \mathrm{MPa}$ ) proučavani su strani uključci raspoređeni po granicama zrna i u samim zrnima.

Po granicama zrna uključci dostižu veličinu $40-50 \mu \mathrm{m}$ i sadrže Si i Ti. Veliki uključci bakra otkriveni su unutar zrna. Mali uključci (veličine do $10 \mu \mathrm{m}$ ) na bazi $\mathrm{Al}$ i Si javljaju se kako u granicama zrna tako i unutar samih zrna. Neznatan je broj malih uključaka koji sadrže Mg, Zn, Ni i Cr. Prisutni su takođe i uključci složenog sasta-va tipa Al$\mathrm{Fe}-\mathrm{Ti}$, Si-Cr-Sn i Pb-Sn.

Nečistoće poput $\mathrm{Al}, \mathrm{Mg}$, Si i Fe, prisutne u platinskim legurama, nakon zagrevanja na vazduhu $\left(1.400^{\circ} \mathrm{C}, 50 \mathrm{~h}\right)$, nalaze se prvenstveno u oksidnom obliku, dok se nakon žarenja u vakuumu $\left(1.400^{\circ} \mathrm{C}, 2 \mathrm{~h}\right)$ registruju u elementarnom stanju. 
Ispitivanjem legure sastava PtRh20Pd10 Ir0,1Au0,1 pokazano je da strani uključci sadrže deseti deo procenta $\mathrm{S}, \mathrm{C}, \mathrm{P}$ i $\mathrm{Pb}$ i drugih štetnih nečistoća [23].
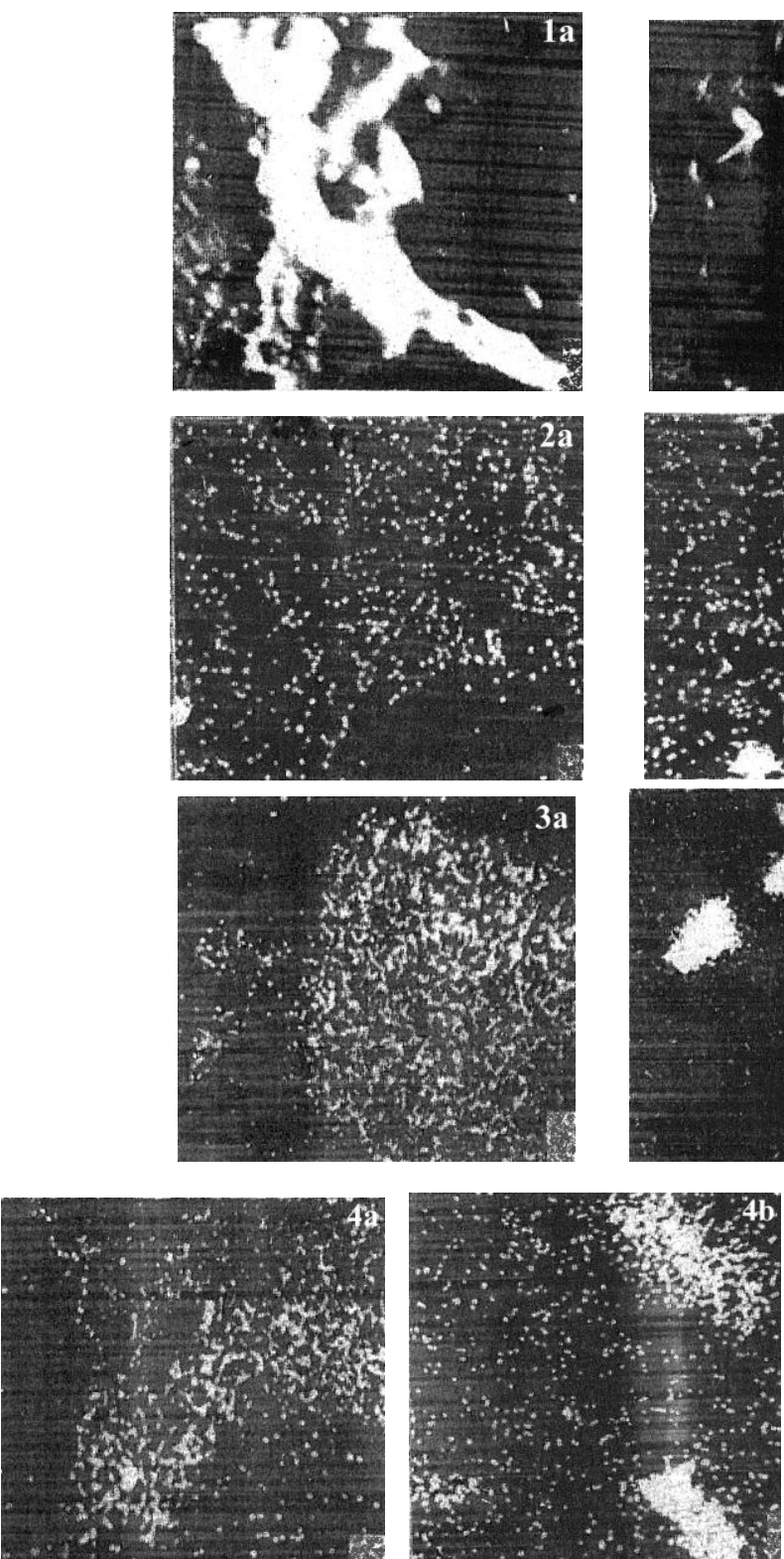

Sl. 2. Standardni prikaz područja uzorka sastava PtRh20Pd10Ir0,1Au0,1 sa uključcima nečistoća

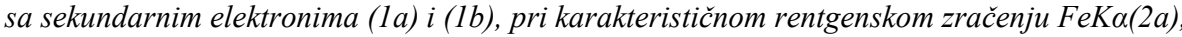

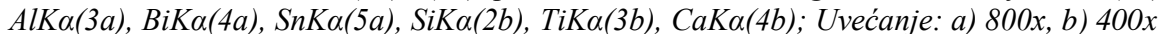

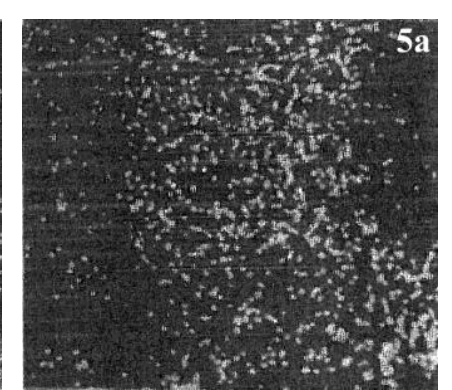

Na slici 2. dat je standardni prikaz područja uzorka sastava PtRh20Pd10Ir0,1 Au0,1 sa uključcima nečistoća kako po granicama zrna, tako i unutar zrna, pri karakterističnom zračenju.
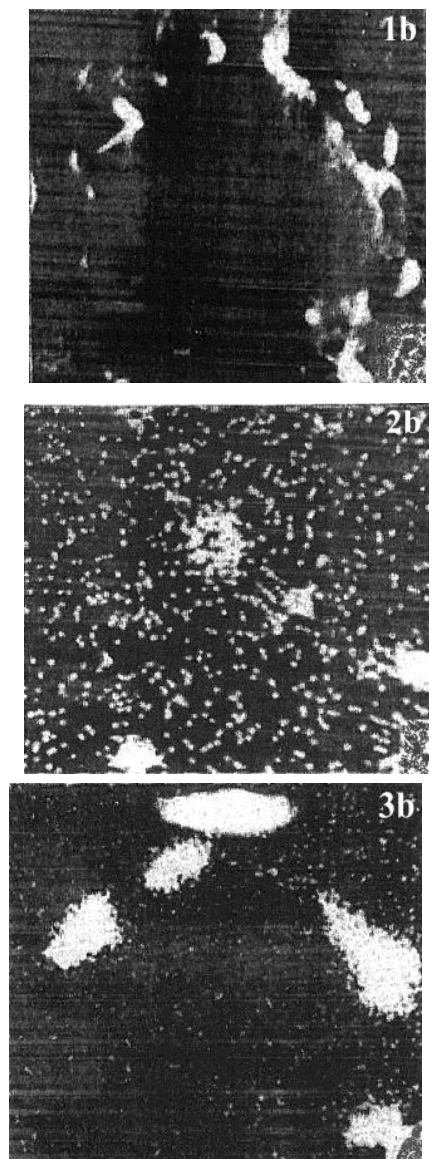

\section{.}


Očigledno je da, u području gde su prisutni uključci obogaćeni $\mathrm{Fe}, \mathrm{Al}, \mathrm{Si}, \mathrm{Ca}$, $\mathrm{Ti}, \mathrm{Bi}$ i $\mathrm{Pb}$ lokalna koncentracija nečistoća kreće se od 5-40\%.
Takođe, zapažena je mogućnost prisustva, na različite načine nastale uključke obogaćene $\mathrm{Si}, \mathrm{Ca}, \mathrm{Al}, \mathrm{Ag}, \mathrm{As}$ i Pb. (slika 3-6 ).

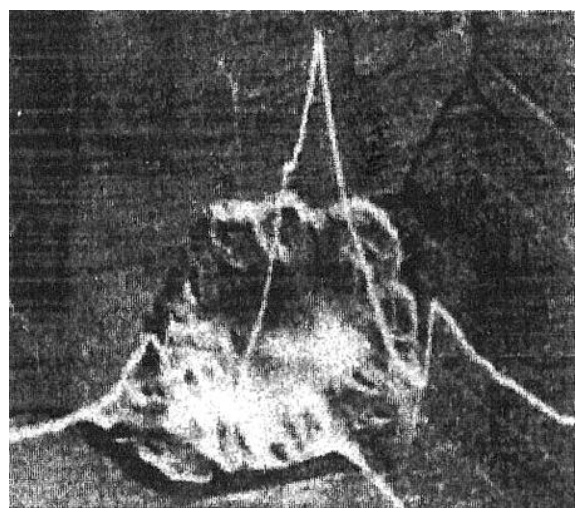

Sl. 3. Standardni prikaz područja uzorka sastava PtRh7 sa uključcima $i$ linijskog rasporeda Si u njemu pri Ka zračenju

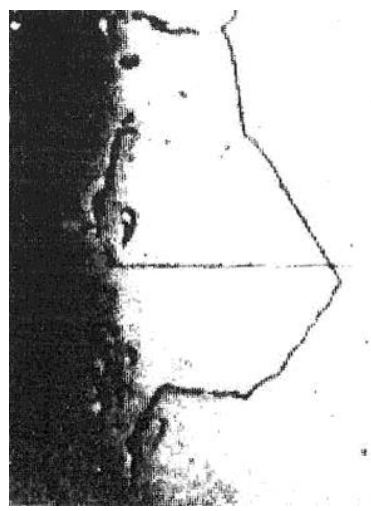

a

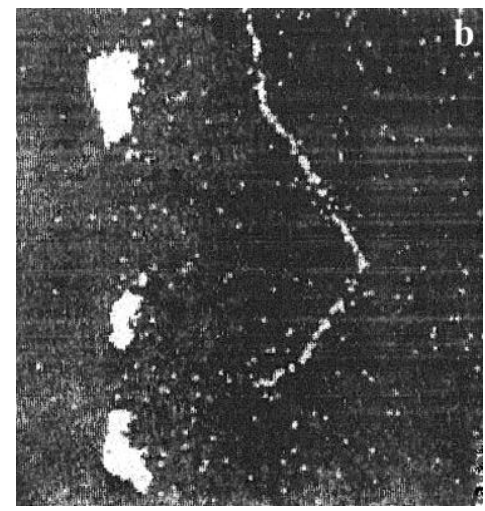

Sl. 4. Oblast razaranja uzorka PtRh25 s uključcima, sa sadržajem Ag sa sekundarnim elektronima (a) i pri rentgenskom izdvajanju AgKa (b) (uvećanje 360x)

a

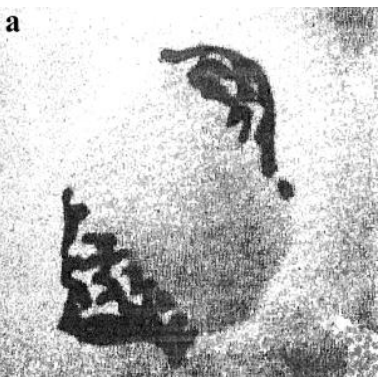

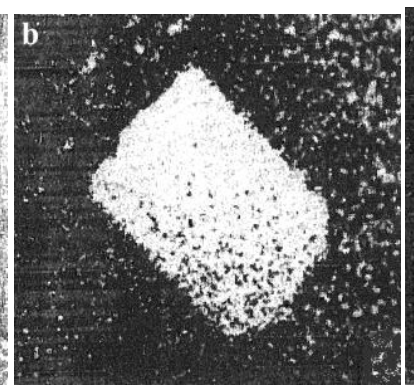

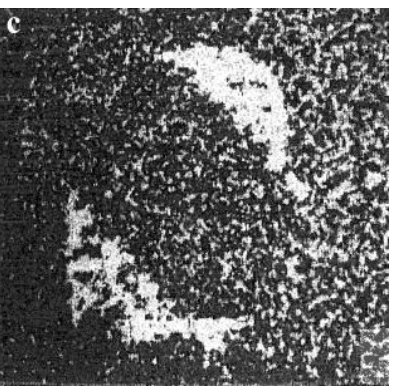

SI. 5. Prikaz dela uzorka platine sa uključivanjem sekundarnih elektrona

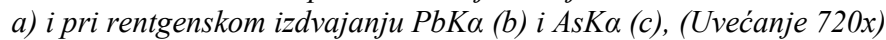



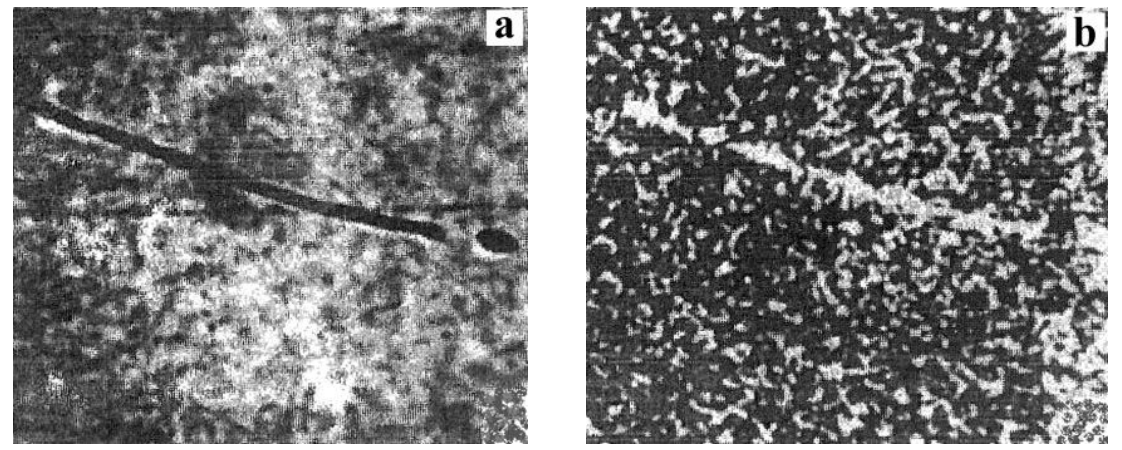

Sl. 6. Prikaz dela uzorka legure PtIr4 sa uključcima koji sadrže Pb, sa sekundarnim elektronima (a) i pri rentgenskom izdvajanju PbKa (b) (uvećanje 850x)

U većini slučajeva strani uključci u običnim svetlosnim mikroskopom, kako je platinskim legurama mogu se videti pod prikazano na slici 7.

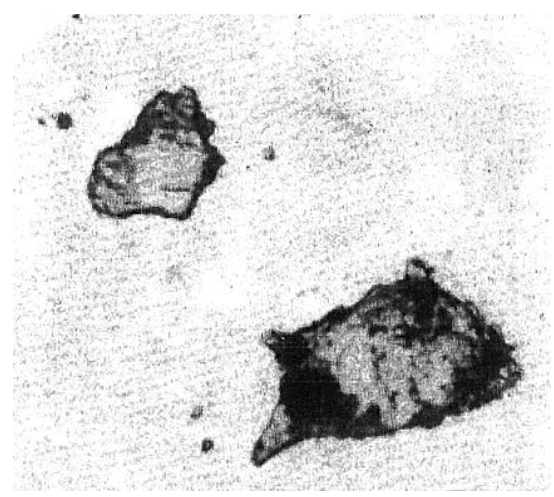

Sl. 7. Uključak u leguri PtRh20Pd10Ir0,1Au0,1 posmatran pod svetlosnim mikroskopom

Pri ispitivanju mikrostrukture čiste 10 min, kako je prikazano na slici 8., platine nakon puzanja na $1.350^{\circ} \mathrm{C}$, pri mogla su se primetiti karakteristična naprezanju od $13 \mathrm{MPa}$ u trajanju od staklasta izdvajanja.

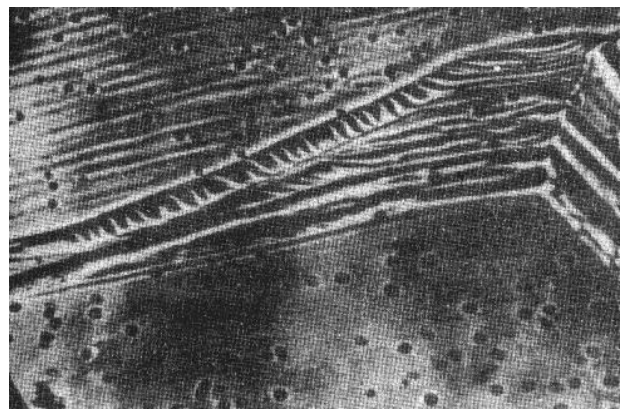

SI. 8. Mikrostruktura čiste platine nakon puzanja na $1.350^{\circ} \mathrm{C}$, pri naprezanju od $13 \mathrm{MPa}$, u trajanju od 10 min (uvećanje 300x) 
Slična izdvajanja bila su predmet istraživanja legure PtIr4, gde je primećeno da na temperaturi višoj od $1.300^{\circ} \mathrm{C}$ površina uzorka pokrivena je mno- gobrojnim malim tečnim kapljicama, koje se postepeno slivaju obrazujući velike providne kapi, kako je prikazano na slici 9.
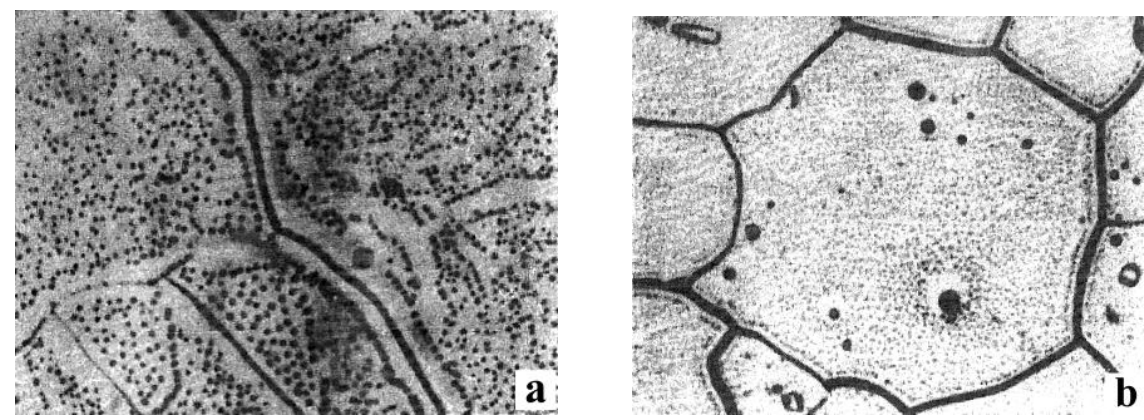

S1. 9. Površina legure PtIr4 s obrazovanjem silikatnih kapljica nakon žarenja na $1.400^{\circ} \mathrm{C}$ : a) 4 h, uvećanje 500x; b) 300 h, uvećanje $100 x$

Granice i subgranice javljaju se istovremeno kao zona izdvajanja i dalje, odvođenja tečnosti. Izdvojena tečnost ote-

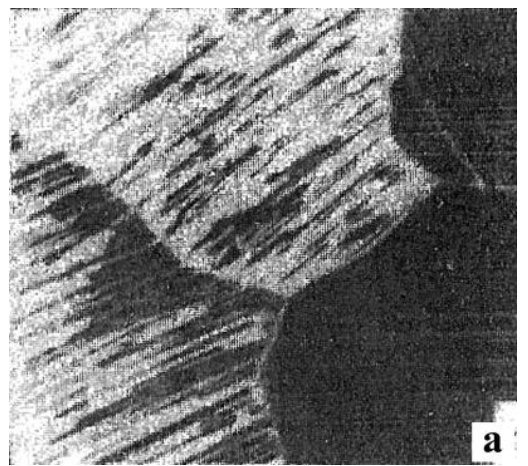

Žava klizanje po ravni (111) unutar zrna, kako je prikazano na slici 10 .

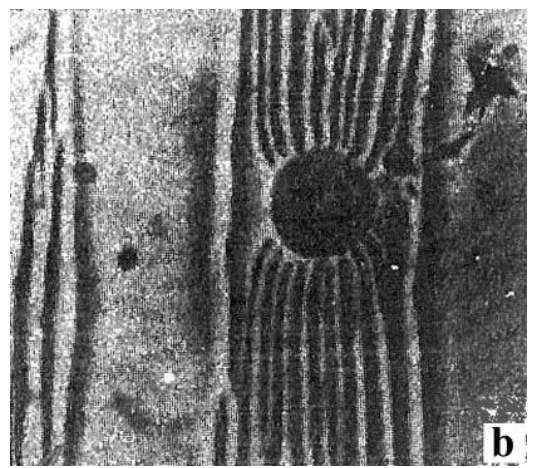

SI. 10. Linije klizanja unutar zrna obrazovane na površini platine pri zagrevanju na vazduhu: a) do $1.300^{\circ} \mathrm{C}$, uvećanje $200 x$; b) preko $1.300^{\circ} \mathrm{C}$, uvećanje $500 x$

Ukoliko je brzina zagrevanja metala do $1.300^{\circ} \mathrm{C}$ prilično velika, stvaranje linija klizanja je malo verovatno. Samo u izuzetno nekontrolisanim slučajevima na površini platine, unutar zrna mogu se istovremeno opaziti mala količina linija klizanja i tečne faze, kako je prikazano na slici $10 \mathrm{~b}$.

Odsustvo linija klizanja u prisustvu tečnosti (kapljica) na površini metala povezano je sa tim, da su sve kapi sjedinjene u tanak film tečnosti koji sprečava stvaranje sloja adsorbovanog kiseonika, pa samim tim i stvaranje linija klizanja. Očvrsle kapi tečnosti nisu reagovale sa sonom i azotnom kiselinom, ali su se odlično rastvarale u fluorovodoničnoj kiselini. Mikro-analiza očvrslih kapi pokazala je prisustvo: $8 \% \mathrm{Si}$; $10 \% \mathrm{Al} ; 10 \% \mathrm{Ca} ; 0,1 \% \mathrm{Ni} ; 0,1 \% \mathrm{Fe} ; 0,1 \% \mathrm{Mn}$ i $0,1 \% \mathrm{Mg}$. Pored nabrojanih elemenata prisutni su bili $\mathrm{Pb}$ i $\mathrm{Na}$. 
Spektralna analiza pokazala je da zagrevanjem platine, u trajanju od $800 \mathrm{~h}$, dolazi do postepenog smanjenja sadržaja nečistoća poput $\mathrm{Si}, \mathrm{Fe}, \mathrm{Ni}, \mathrm{Ca}$ i $\mathrm{Mg}$. Obrazovanje tečne silikatne faze povezano je sa smanjenjem otpora puzanju platine $\mathrm{i}$ njenih legura, pri sadržaju nekih od navedenih primesa, budući da međusloj istopljenih silikata na ravnima granica zrna verovatno ubrazava klizanje.

\section{ZAKLJUČAK}

$\mathrm{Na}$ osnovu dosadašnjih rezultata istraživanja, može se sledeće zaključiti:

$\mathrm{U}$ realnim uslovima u nastajanju ravnotežne segregacije može uzeti učešće desetak nečistoća i taj proces jako zavisi od njhovog međusobnog dejstva, dejstva s metalom osnovom i legirnim elementima uz istovremenu zavisnost temperaturno - vremenskog faktora.

Ukoliko je viša temperatura metala pri hlađenju, utoliko je više i značajnije stvaranje para vakancija-intersticijski atom koji difunduje ka granicama zrna, pojačavajući neravnotežnu segregaciju nečistoća.

Uporedo sa ravnotežnom i neravnotežnom segregacijom nečistoća u platinskim legurama primećene su skupine nečistoća $u$ obliku stranih uključaka. U tim uključcima nečistoće se nalaze, u obliku čvrstih jedinjenja, najčešće u obliku oksida. Čestice oksida dospevaju u leguru, u procesu topljenja u keramičkim loncima ili nastaju u vidu silikatnih uključaka u procesu zagrevanja. Veličina tih uključaka dostiže stoti deo mikrometra

Nečistoće poput $\mathrm{Al}, \mathrm{Mg}$, $\mathrm{Si}$ i Fe, prisutne u platinskim legurama, nakon zagrevanja na vazduhu $\left(1.400^{\circ} \mathrm{C}, 50 \mathrm{~h}\right)$, nalaze se u oksidnom obliku, dok se nakon žarenja u vakuumu $\left(1.400^{\circ} \mathrm{C}, 2 \mathrm{~h}\right)$ registruju u elementarnom stanju.

Ispitivanjem legure sastava PtRh20 Pd10Ir0,1Au0,1 pokazano je da strani uključci sadrže deseti deo procenta S, C, P i $\mathrm{Pb}$ i drugih štetnih nečistoća
Segregacija nečistoća u platinskim legurama uslovljena je prirodom nečistoća, njihovom koncentracijom, raspodelom $\mathrm{u}$ zapremini metala, uzajamnim dejstvom sa osnovnim i legirnim komponentama, kao i temperaturno - vremenskim faktorom. Moguće je očekivati da kao rezultat uzajamnog dejstva štetnih nečistoća s platinskim metalima koji ulaze u sastav legure, nastaju sniženja visokotemperaturne otpornosti legure i povećanje verovatnoće krtog preloma na visokim temperaturama

\section{LITERATURA}

[1] H. Gavin, Platinum Met. Rev. 54 (2010) 166.

[2] E. Preston, Platinum Met. Rev.4 (1960) 48.

[3] D. F. Lupton, J. Merker, B. Fischer, R. Völkl, $24^{\text {th }}$ International Precious Metals Cconference, Williamsburg, Virginia, USA, 1-14 June 2000.

[4] Y. Ning, Z. Yang, H. Zhao, Platinum Met. Rev.4 (1996) 80.

[5] N. Yuantao, Y. Zhengfen, Platinum Met. Rev. 43 (1999) 62.

[6] B. Trumić, D. Stanković, V. Trujić, J. Min. Metall., Sect. B 45 (1) B (2009) $79-87$.

[7] B. Wu, G. Liu, , Platinum Met. Rev. 41 (1997) 81.

[8] M. Funabikia, T. Yamadaa, K. Kayanoa, Catal. Today 10 (1991) 33.

[9] T. Biggs, S.S. Taylor, E. Van der Lingen, Platinum Met. Rev. 49 (2005) 2.

[10] John C. Wright, Platinum Metals Rev., 2002, 46 (2), 66.

[11] T. Biggs, M. B. Cortie, M. J. Witcomb, L. A. Cornish, Platinum Metals Rev., 2003, 47, (4), 142.

[12] T. Biggs, M.J. Witcomb, L.A. Cornish, Materials Science and Engineering A273-275 (1999) 204.

[13] F. Xiao, F. Zhao, D. Mei, Z. Mo, B. Zeng, Biosens. Bioelectron. 24 (2009) 3481 . 
[14] K. T. Jacob, S. Priya, and Y. Waseda, Metall. Mater. Trans. A 29A (1998) 1545.

[15] G. Dereli, T. Cagin, M. Uludogan, M. Tomak, Philos. Mag. Lett. 75 (4) (1997) 209.

[16] P. Battaini, Platinum Met. Rev. 55 (2011) 74.

[17] J. Luyten, J. De Keyzer, P. Wollants, C. Creemers, Calphad 33 (2009) 370.

[18] B. Trumic, L. Gomidželovic, S. Marjanovic, V. Krstic, A. Ivanovic, S. Dimitrijevic, Pt-Materials Testing, 55 (2013) 38.

[19] Ритвин, Е. И., Медовој, Л. А.: Влиание физико-химическој следи на жаропрочност мераллических материалов, Москва, Наука, 1974

[20] Савицкиј, Е. М., Полјакова В. П., Горина, Н. Б., Рошан, Н. Р.: Металоведение платинових металов, Москва, Металургија, 1975.

[21] Захаров, М. В., Захаров, А. М.: Жаропрочние сплави, Москва, Металургија, 1983.

[22] Ритвин, Е. И.,: Жаропрочност платинових сплавоажв, Москва, Металургија, 1987.

[23] B. Trumić, L. Gomidželović, M. Bugarin, Mining and Metallurgy Engineering Bor, 1/2015, str. 141-148. 